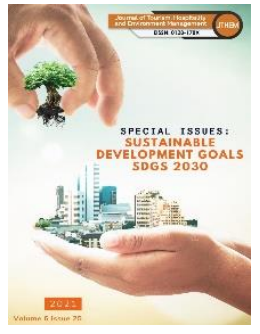

\author{
JOURNAL OF TOURISM, \\ HOSPITALITY AND \\ ENVIRONMENT MANAGEMENT \\ (JTHEM) \\ WwW.jthem.com
}

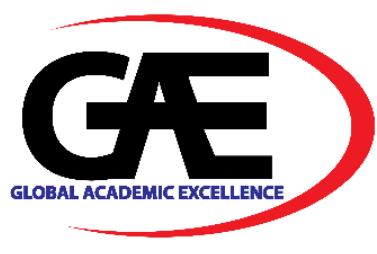

\title{
THE FRAMEWORK OF INTEGRATED CIVIC EDUCATION FOR FOSTERING MULTICULTURAL TOLERANCE
}

\author{
Sakinah Salleh ${ }^{1 *}$, Alwi Mohd Yunus ${ }^{2}$, Rahimah Embong $^{3 *}$ \\ 1 Faculty of Human Sciences, Universiti Pendidikan Sultan Idris. \\ Email: sakinah.salleh@fsk.upsi.edu.my \\ 2 Faculty of Information Management, UiTM \\ Email: alwiyunus@uitm.edu.my \\ 3 Faculty of Islamic Contemporary Studies, Universiti Sultan Zainal Abidin, Terengganu \\ Email: rahimahembong@unisza.edu.my \\ Corresponding Author
}

\section{Article Info:}

\section{Article history:}

Received date: 01.07.2021

Revised date: 16.08 .2021

Accepted date: 30.09 .2021

Published date: 31.10 .2021

\section{To cite this document:}

Salleh, S., Yunus, A. M., \& Embong, R. (2021). The Framework Of Integrated Civic Education For Fostering Multicultural Tolerance. Journal of Tourism, Hospitality and Environment Management, 6 (25), 1527.

DOI: $10.35631 /$ JTHEM.625002.

This work is licensed under $\mathrm{CC}$ BY 4.0 (c) (2)

\section{Abstract:}

This article aims to discuss the implementation of civic education as a means to foster multicultural tolerance in Malaysia. The prevailing racial disparity due to racial hate, racist remarks, and an unbecoming statement from political and community leaders indicate a serious breach of harmonious racial relationships among various races in Malaysia. Conflicts among diverse societies can lead to disintegration and social problems. The internalization of multicultural tolerance, especially among the younger generation is an effective effort to avoid conflicts within societies since multicultural tolerance is one of the key ingredients for harmonious co-existence. Due to these multicultural differences, education has been perceived as an instrument for promoting national unity and harmony among citizens. Therefore, civic education should be given priority to instil a sense of national love and to build a virtuous and responsible society. Based on the descriptive literature review method, this paper seeks to propose an integrated civic education framework inclusive of three elements; curriculum, teaching approach, and teacher's competency to foster a multicultural tolerance among the young generation. This framework of integrated civic education is expected to help in solving the issues of multicultural tolerance and develop social cohesion among the young generation. Consequently, it can cultivate a sense of respect among members of our multiracial society and ultimately promote national peace and harmony. 


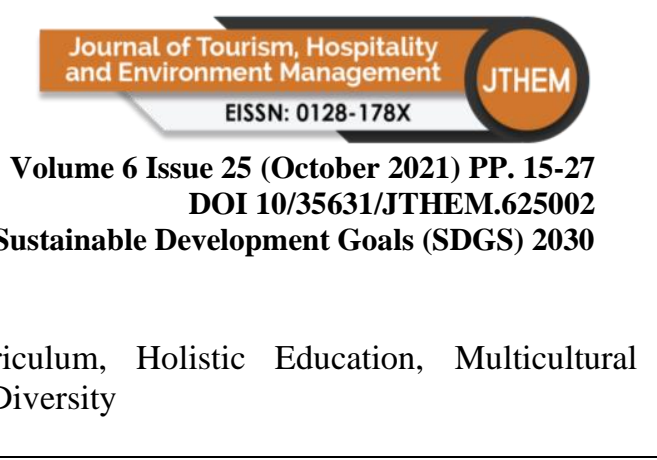

Keywords:

Special Issue: Sustainable Development Goals (SDGS) 2030

Civic Education, Civic Curriculum, Holistic Education, Multicultural

Education, Tolerance, Cultural Diversity

\section{Introduction}

Malaysia is a multi-ethnic and multicultural country that have differences in language, religion and culture. Without multicultural tolerance, people who live in multicultural society would not be able to unite as a community because social issues or even social conflicts would always arise (Wazler,1997). To nurture tolerance within society of diverse races and ethnicity, civic education in schools embeds the element of racial harmony and tolerance among students and also one of the means to develop social cohesion among society and to promote individual members as a tolerant citizen. Civic education is formulated based on the education system in Malaysia which is very much focused on the National Education Policy (NEP) established in 1988 with the aim to:

"developing the potential of individuals in a holistic and integrated manner, so as to produce individuals who are intellectually, spiritually, emotionally and physically balanced and harmonious, based on a firm belief in and devotion to God. Such an effort is designed to produce Malaysian citizens who are knowledgeable and competent, who possess high moral standards, and who are responsible and capable of achieving high level of personal well-being as well as being able to contribute to the harmony and betterment of the family, the society and the nation at large"

Based on NEP, elements like good personality and moral values are important in ensuring that the aim of the National Philosophy of Education is achieved. One way to achieve this goal is to have Civic Education to be taught in school for it can serves as a platform to achieve harmony, unity in diversity, positive relationship, good personality and balanced individual. This is to ensure that the objectives of forming citizens who know their rights, are responsible and noble can be realized.

\section{Problem Statement}

The prevailing scenario in Malaysia recently shows the problem of tolerance among the various races in Malaysia. Among the issues related to multicultural tolerance are vernacular schools (Sinar Harian, 20208 September) language issues, Arabic writing scripts implementation issues (Sinar Harian, 20209 December), lantern installations in schools, flag issues (Berita Harian, 2020, 24 Ogos) and a host of other issues that indicate the lack of tolerance among multicultural people in Malaysia. These issues have created tension and distrust in the multicultural Malaysian community. This intolerance is also evident in social media that evokes racial sentiment. For example, the issue of language has created tension and distrust among community as promoting the Malay language, which is the national language, could be viewed by the other ethnic groups including non-Malay Bumiputera, as a threat to their culture and identity (Mahmood, 2014). There are also many incidents happened that show that the spirit of unity has faded due to the lack trust and tolerance in the community. Besides that, social tensions can also happened because of the negative beliefs and attitudes towards other groups, which can lead to hatred, intolerance, stereotyping, stigmatization, fear of the other 


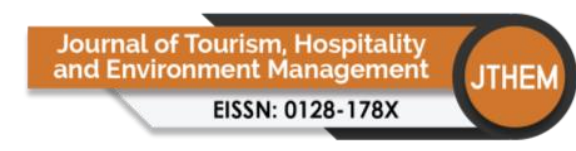

Volume 6 Issue 25 (October 2021) PP. 15-27

DOI 10/35631/JTHEM.625002

Special Issue: Sustainable Development Goals (SDGS) 2030

(Moorthy et al, 2021). Consequently, social conflicts would arise if all the issues cannot be managed or resolved. Due to these multicultural differences, education has been perceived as an instrument for promoting national unity, social equality, and economic development. Therefore, civic education should be given priority to instil a sense of national love and to build a virtuous and responsible society. This is because, civic education emphasizes three essential elements namely civic knowledge, civic values and civic skills. These three aspects should emphasize students' awareness of Malaysia as a sovereign nation with a vision to uphold integrity and anti-corruption; with the constitution that protects and values the rights and responsibilities of her citizens. However, as mentioned by Moorthy et al, (2021), contemporary civic and citizenship education in many countries has not been able to resolve social conflicts. According to Moorthy et al, (2012), the implementation of the values, more often than not, has been biased and propagandist in nature, as well as prompting limited enthusiasm among teachers in the delivery of civic and citizenship education. Furthermore, studies by Mahmood (2014), shows the gap between teachers' perception of civic and civic education with their teaching practices. While Balakrishnan (2021) has suggested that there must be collaboration and cooperation between different agencies to ensure that the tension between religiosity, cultural norms and ethics would be able to find some common ground. Therefore, based on the problem above discussion, this paper aim to discuss the implementation of civic education in the schools as a mean to foster multicultural tolerance in Malaysia. Besides that, this article will also seeks to address civic curriculum framework inclusive of element for promoting a multicultural tolerance among students, who can play a big role as a new generation in fostering social positivity in societies.

\section{The Implementation of Civic Education in The National Curriculum}

Education is one of the mechanisms to instill unity among members of the community, to maintain the democratic way of life, to promote social justice and to guarantee the freedom of religious, cultural beliefs and diverse traditions of the Malaysian society. According to Mahmood (2014), there were some similarities between Western and Malaysian notions of civic education in relation to the matter of civic education specifically to build good personal and patriotic citizens. For Malaysia, the mission of the Ministry of Education Malaysia is to provide a world class education, to ensure the development of individual's potentials and to fulfil the nation's aspirations. These are reflected through the initiatives undertook by the government in 1988, whereby the National Education Philosophy (NPE) was formulated which is the core of all educational programs and activities at all levels of school, from pre-school until tertiary education with the aim to produce a good Malaysian citizen. Later in 1989, the new Secondary School Curriculum (KBSR) and Integrated Curriculum for Primary School (KBSM) was implemented (Kementerian Pendidikan Malaysia, 1989; 1990). In narrowing the gap of the multicultural society in Malaysia, the government again introduces the new plan "National Education Blueprint 2006-2010". All of the above shows that the government of Malaysia has always been promoting education for peaceful co-existence and acceptance of multiculturalism and multi-sectarianism, based on its educational curriculum (Ishak, 2009).

Civic Education in schools was previously called the subject of Civic Education and Citizenship. The civic education created is also aimed at educating students about their role, rights and responsibilities in society and nation to produce unitedly patriotic citizens and citizens who can contribute to the well-being of the community, nation and the world. At the same time, it is intended to ensure that the planning in education would produce generations that love the nation, responsible and dignified. The Civic Education is taught through five 


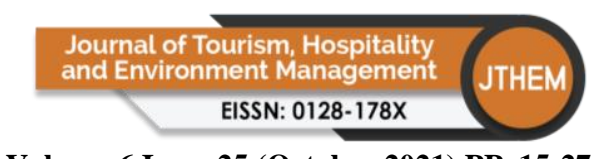

Volume 6 Issue 25 (October 2021) PP. 15-27

DOI 10/35631/JTHEM.625002

Special Issue: Sustainable Development Goals (SDGS) 2030

subjects, namely Bahasa Melayu, Bahasa Inggeris, History, Islamic Studies and Moral Education. It is a subject introduced in the national primary and secondary schools with the aim of producing patriotic and responsible Malaysian citizens. In this context, the school is responsible of ensuring that knowledge, skills and ethics are transferred and students are transformed to be knowledgeable and skilled in exercising civic rights and duties.

In June 2019, Civic Education was introduced at all schools throughout the nation to expose students to the concept of values and ethics in subjects like Bahasa Melayu, English, Islamic Studies, Moral and History. It is implemented in a new and holistic way, with the hope of giving birth to a generation of vibrant and civic-minded Malaysian citizens by 2030. The Civic Education Exemplar Module; School Assembly Manual and Pure Practice; and Civic Education Practice Manual in the Curriculum help teachers to implement civic education as desired. The implementation of Civic education are integrated and holistic by emphasizing Literasi Sivik (civic literacy) in the classroom and Amali Sivik (civic practice) outside the classroom. Civic literacy encompasses knowledge of citizenship, socio-citizenship and citizenship actions that are embedded in the curriculum which students need to master. Meanwhile, Civic Practice gives students the opportunity to apply civic literacy practically. The application of civic literacy is implemented in school assemblies, co-curricular activities, and school programs. Civic Education is conducted for an hour in the fourth week of each month in Bahasa Melayu, English, Islamic Studies, Moral and History.

\section{Civic Education as An Approach for Promoting Multicultural Tolerance}

According to the dictionary of Dewan 4th Edition, civics means the knowledge of the people's conduct or the feeling of responsibility towards the society. It is to form a citizen that knows the rights, able to take responsibilities and to have good manners who will contribute to the welfare of the society (Mazlee Malik, 2019). The word civic is associate with positive behaviors or values, such as truthfulness and fairness, which constitutes good values, wanting to obtain those values, and then acting on them to perform good deeds such as kindness, compassion, justice, perseverance and work ethic.

\section{Multicultural Tolerance}

Multiculturalism sets people apart from limited societies, ensuring their personal autonomy, freedom and social citizenship and offering a way of life that is shared collectively. It is a system of values and actions that acknowledges and supports the participation in an institution or community of all ethnic groups. Multicultural education can be a platform to cultivate the aspect of harmony, unity in diversity, positive relationship, good personality and balanced individual. Therefore, the ultimate aim of multicultural education in this study is to create consensus on shared values and good conduct among students. They should understand and respect each other, and compromise on an equal basis to reach common grounds. The essential aspects of school learning required in the education system in an attempt to internalize student's tolerance (Sahal et al, 2018) and one of the means to construct society is to cultivate tolerant citizens among young generation who can respect differences and recognize diversity among each other.

Tolerance derived from the Latin word "tolerare" which means patience and self-restraint can also mean an attitude of mutual respect or considerate towards other people's opinions, thoughts and beliefs. means to be tolerant or tolerant of opinion (Sahal et al, 2018). According to Fakhri (2012) tolerance is recognition of other people's varying views and justice towards the Copyright (C) GLOBAL ACADEMIC EXCELLENCE (M) SDN BHD - All rights reserved 


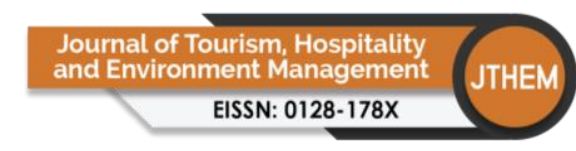

Volume 6 Issue 25 (October 2021) PP. 15-27

DOI 10/35631/JTHEM.625002

Special Issue: Sustainable Development Goals (SDGS) 2030

individuals holding such different views. It is the capacity, or the practice, to consider and value others' beliefs or practices. Tolerance is looked as the reverence and appreciation for the rich diversity of the cultures in our world that correlated with the creation values within a person (Koriakina et. al., 2019). This is used as a tool to accept others as they are. Tolerance is one of the attitudes that every individual or society should possess, but the process of identifying it often leads to uncertainty and disagreement (Afdal, 2005). Without this attitude, the integrity of society can be divided between one community and another (Wazler, 1997). This tolerance is also part of the conditions of success in the process of assimilation in people's lives. Initially, tolerance in the context of multicultural education should refer to three specific curricula domain; the ideological, formal and perceived curricula (Afdal, 2005). Therefore, tolerance in this study will be focused on the concepts of respect, understanding and the practice of tolerance among students.

\section{Fostering Multicultural Tolerance through Civic Education}

Education in multicultural society must take into consideration the notion that each society has different set of societal values and cultural values (Yusof \& Esmaeil, 2017). In other words, character education is significant in fostering peace and harmony, unity in diversity, positive relationship, dynamic and good personality, balance individual in a multiethnic and multicultural society like Malaysia (Salleh, \& Mohd. Yunus, 2020). This is normal and deeply rooted in each of the social setting. Therefore, by emphasizing on the concept of multiculturalism in civic education, it may foster the ethics and spirituality of every student to meet the challenges of adult life, so that they can resolve conflicts harmoniously, intellectually, and adhere to principles of multicultural tolerance when in critical situations. Teachers need to act as effective facilitators to ensure that students are developed with strong support and foundation through the learning process in and out of the classroom (Tamuri \& Hussin, 2011).

According to the study by Hashim et al, (2015), there were four strategies such as nurturing national integration, encouraging interactions among multi-ethnic students, stimulating acceptance and tolerance between students and creating school environment that reflects diversity of ethnics. There was a study by Jamaluddin (2011), which focused on the religious tolerance models among multi-ethnic youths in Malaysia. The study revealed that, other than attitude and perception factors, religious tolerance behaviour and its associated factors contributed much to racial harmony in multicultural and diverse races in Malaysia. In other words, Malaysians need to be exposed thoroughly to the association and interaction between people of other faiths and ethnicities. Bad attitudes such as prejudice, stereotype, racism, discrimination and ethnocentrism should be avoided to maintain harmonious living. Jamaluddin (2011) stated a tight relationship between Muslim and non-Muslim students is due to lack of association between them especially after school hours, lack of knowledge and indepth understanding of the culture, practices, and customs of different races. The problem of this discordant relationship may be because the student does not understand the concept of socializing. Even as a curriculum implementer, teachers should study every student's culture and have in-depth knowledge of students to improve their teaching performance.

According to Fisher \& Kartikasari (2001), social dissension is caused by the polarization, distrust, and hostility between different groups. This theory may be the reason why the unity of the nation is difficult to achieve, where multiracial groups have negative thoughts and perceptions towards others. This is in line with the study by Ahmad et al, (2010), on the diversity of students and schools in Pahang showed that students still have a moderate and Copyright (C) GLOBAL ACADEMIC EXCELLENCE (M) SDN BHD - All rights reserved 


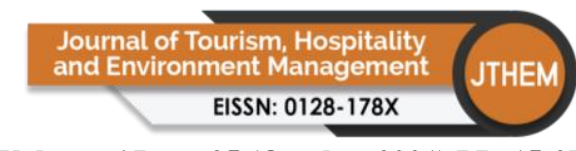

Volume 6 Issue 25 (October 2021) PP. 15-27

DOI 10/35631/JTHEM.625002

Special Issue: Sustainable Development Goals (SDGS) 2030

unsatisfactory perspective on the concept of cultural diversity in schools. This is because schools and teachers are less likely to give students exposure and encouragement to accept diversity in schools. This problem complicates the task of education, which is to devise ways to avoid conflicts or resolve them peacefully by respecting the culture and spiritual values of each other.

It is inevitable that education model in Malaysia must accept the core fact of embracing and accepting multiracial and diversity of the social demography of different society, so it can fit into the needs and requirement of the unique multi-ethnic society in Malaysia (Adnan \& Smith, 2001). One of the subjects that can help to render the intolerance among multicultural society is through civic education. Civic education includes a broad range of concepts such as positive school culture, moral education, caring school communities, social emotional learning, positive youth development, civic education, and service (Pala, 2017). Those elements woul help to promote unity in diversity, positive relationship, dynamic and good personality, balanced individuals (Embi, 2015) in a multi-ethnic and multi-cultural society in Malaysia. Besides that, civic education need to be implemented because it can contribute to strong character development (Dalton \& Crosby, 2010).

\section{Instilling Values in Promoting Multicultural Tolerance}

Education should propagate universal value or shared value such as trustworthiness, respect, unity, understanding, helping each other in the process of teaching and learning. Sahal et. al, (2018), propose multicultural education that prioritize basic skills for the students such as building attitudes, awareness and skill that enables students to work for social justice, so that this young generation can be exposed to positive attitudes towards racial differences (Fakhri, 2012).The act of instilling the universal values of education is done by focusing on several factors such as having a common medium of instruction; attending the same school which enable pupil of diverse races to meet and interact; providing equal opportunity and access of learning; formulate and initiate a change strategy that reforms the total school environment (Salleh, 2018): (a) language and dialect of the school, (b) school policy and politics, (c) learning styles of the school, (d) school staff's in terms of attitudes and (e) action must be given prior attention. The values learned will be practiced in daily life, which in turn may result in civic behaviors, such as volunteering; individual acceptance of different races, religions, and ethnicities; avoiding corruption and crime; and demonstrating trust and integrity. This can also be achieved by highlighting the students' aspirations such as knowledge, thinking skills, leadership skills, ethics and spirituality; and national identity.

The important element in a holistic education, is the emphasis on value-based learning. In value-based learning, instilling virtues such as empathy, courage, truthfulness, understanding, and fairness will aid in the development of harmonious persons, the elevation of individuals to personhood, and the creation of a compassionate community. The home, the religious organizations, and the educational institutions are the three key structures that affect valuebased education. These organisations play a vital role in influencing the minds of the youth of today (Morthy et al,2021). It is critical to rethink learning concept and redirect it on a valuebased structure in order to address diverse social issues (Morthy et al,2021)

Therefore, curriculum needs to be changed according to the dynamic nature of school's environment, curriculum design also must promote and focus on: social tolerance, fair and justice personal development regardless of class and equal access to education, universal Copyright (C) GLOBAL ACADEMIC EXCELLENCE (M) SDN BHD - All rights reserved 


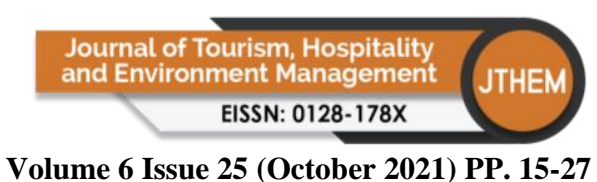

Volume 6 Issue 25 (October 2021) PP. 15-27

DOI 10/35631/JTHEM.625002

Special Issue: Sustainable Development Goals (SDGS) 2030

curriculum and subjects. As mentioned by Koriakina et. al,( 2019), in order to foster the multicultural tolerance, the structure and content of education must be constructed as the determining conditions, for the creation of progressive socially relevant values and inclusive attitudes among students. Not only that, the spirit of openness, tenacity, unprejudiced and transparency (Afdal, 2005) should also be practiced among the multicultural community. Sleeter (2018) recommended that classroom approaches for building bridges between multiethnic students in multicultural education is essential to create and maintain ideological clarity.

\section{The Framework of Integrated Civic Education}

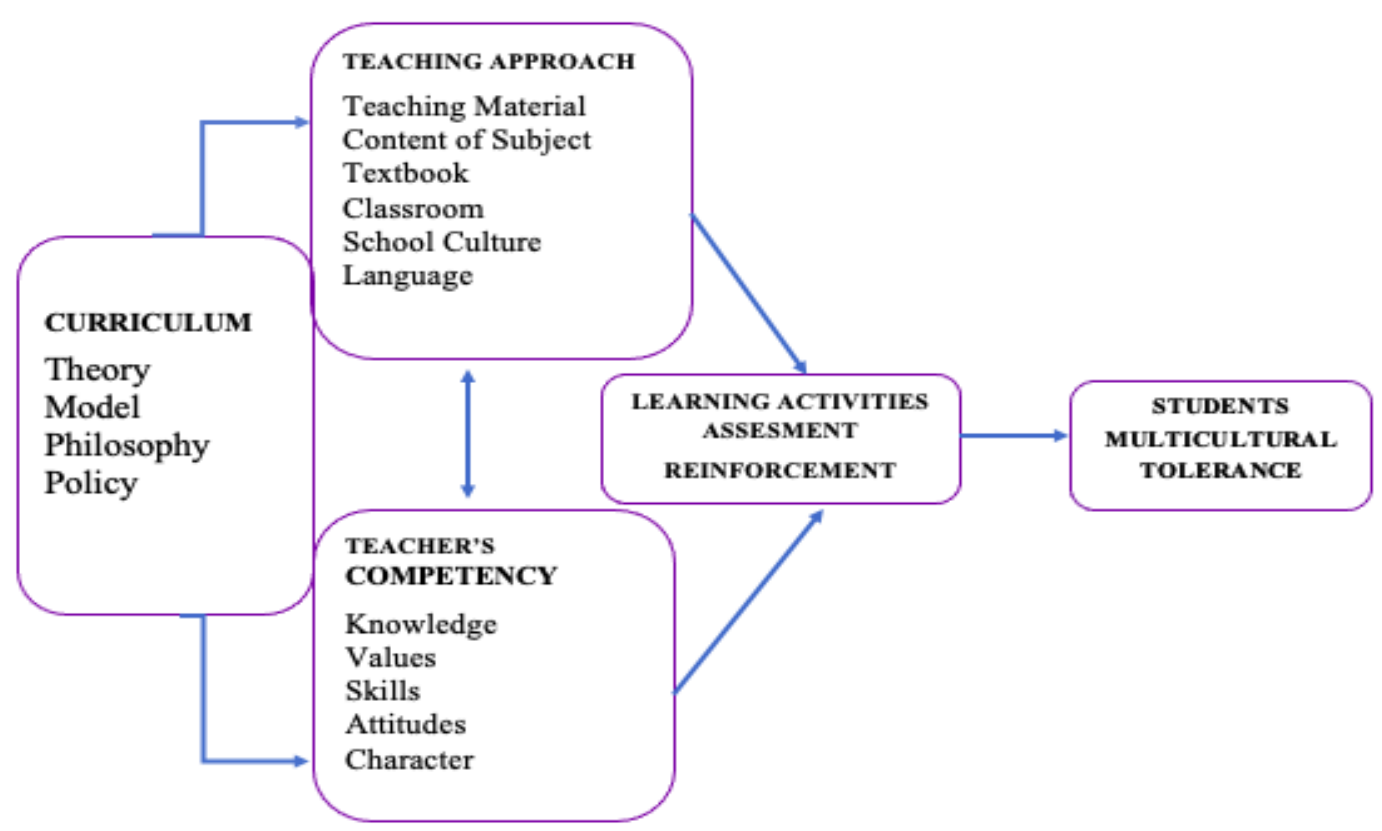

Figure 1: The Framework Of Integrated Civic Education

\section{The Civic Curriculum}

The word curriculum originated from a Latin word of currere which is defined as "to run" (McKimm, 2010). According to McKimm (2010), "to run" is a template used in order for the learning process to take place. Learning by curriculum is to emphasize on the elements of knowledge, skills, and attitude while practicing the elements of teaching, learning and valuation. These elements bring to the justification that the process of learning is important to ensure the end product produced through civic curriculum. The process and product of a curriculum can be translated through a curriculum development model. This is because according to Sheehan (1986), model can be defined as a process of rationalising a relationship designed to the actual setting considering the various factors that influence the relationship. As such, a model is important to drive towards implementation of planning and realization of goals. 


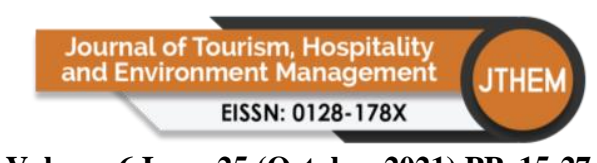

Volume 6 Issue 25 (October 2021) PP. 15-27

DOI 10/35631/JTHEM.625002

Special Issue: Sustainable Development Goals (SDGS) 2030

Curriculum is a scope or the content of a subject which is taught in a school or an educational institution (Kamus Dewan, 2005). Curriculum Development Center, Ministry of Education Malaysia explains that curriculum covers all activities done by students in an educational organisation. Those activities include learning by students, teaching materials and teaching approaches adopted by teachers. Alias et al, (2014), define curriculum as a concept that have gone through reformation steps leaving its effects in the form of ideas, models, and actions embodied in projects in schools and other educational institutions. Meanwhile, according to Adnan \& Smith (2001), curriculum as plans, arrangements and research written in order to meet the educational needs of the students drawn from the students' experiences and the views of experienced teachers.

Curriculum is also described as a means of engaging with the students' experience and the expertise of the teacher in drafting a written document to serve as a guide in achieving the goals in teaching. The formation of a curriculum requires a detailed planning which involves model, approach, philosophy, theory and other elements underpinning the curriculum (Hamdan, 2009). Stenhouse (1975) in his book "An Introduction to Curriculum Research and Development" states that in curriculum there must be two elements, which are firstly, the hidden curriculum. One example is the school culture that results from the interaction between the members of the school. Secondly, official curriculum which is the curriculum that meets the academic demands of students. The presence of these elements would lead to the birth of various models of curriculum development.

The civic curriculum is seen as the heart of the education system, and it can form part of the problem as well as part of the solution. Considering these, civic curriculum will be to some extent successful in eliminating ethnic discordances. Through civic curriculum, students can learn to understand the differences of race and culture and consequently will help to nurture tolerance, acceptance and respect towards each other; understand the unique development of Malaysia; share common values; and working together to achieve the aspiration of Malaysia. Thus, civic educators should render a more effective civic curriculum across subjects with the practice of democratic pedagogy (Carretero et al, 2016). The challenge is to provide civic curriculum that instils unity in the diverse multicultural society. The education policies and implementation practices have to be re-analyzed in order to look into new potentials in line with civic curriculum that could result in closing the conflict gaps between races in society. Aside from the difficulty of executing a policy, it's also vital to comprehend how governance implementers especially teachers view citizenship. (Haniza, 2014).

However, in a state practicing tight control over education policy like in Malaysia, the decision on what is considered as valid knowledge that is the curriculum is not directly in the hands of teachers or students but is the agenda of policy makers. As to ensure civic education to be an integrating factor of racial harmony and unity among races, initiative that is in line with the direction of Malaysia education policy should be implemented. Implementation of civic education would alleviate regional disagreement and to motivate national unification (Haniza, 2014). This is also mentioned by Fakhri (2012, p: 273) "education system need to be analyzed in terms of their potential to aggravate or ameliorate conflict among the different groups in society". The implementation of civic curriculum will help students to be fully equipped on the knowledge of our histories and cultures which form multicultural and multiracial society in our country. This will also lead to the enhancement of respects and understanding in our 


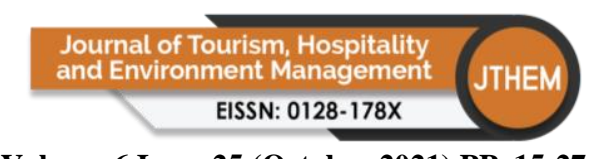

Volume 6 Issue 25 (October 2021) PP. 15-27

DOI 10/35631/JTHEM.625002

Special Issue: Sustainable Development Goals (SDGS) 2030

multicultural and multiracial society which consequently contribute in creating a multicultural tolerance among students.

\section{Teaching Approach}

The Civic curriculum in schools that need to be implemented must include variety of methods not only focus on theory, but also applying the elements of multi-racial tolerance. According to Salleh \& Mohd Yunus (2020), exploratory activities can have a more profound and longterm impact compared to teaching that is based on textbooks and classrooms only. Hands-on methods such as course work need to be explored in the titles provided so that the elements of patriotism contained in the elements learned can be practiced in the lives of students especially after their school years (Salleh \& Mohd Yunus, 2020). This integrated civic curriculum framework is needed to address the various issues that arise in relation to students and learning. This problem can be solved by outlining certain systematic procedures. The problem of creating a dynamic curriculum requires ongoing initiatives to make this field of education explicit in the real world, that need to ensure an be able to instil within students the same values as those inspired by the Philosophy of National Education.

As indicated by Nogueira \& Moreira (2012), given the insufficiency of the educators' current techniques, the execution of civic education as a non-disciplinary curriculum area need a theoretical explanation and a heavy emphasis on teaching practice. In addition, Nogueira \& Moreira (2012), suggested further that it is crucial that the teaching methodology be fit for the subject matter of civic education and captivating projects and activities in the context of essential and engaged citizenship. The curriculum ought to be able to connect whatever is learned to contemporary situation and to other subjects taught. A variety of approaches in teaching, through a variety of approaches using 21 st century learning activities such as the use of teaching aids like video, animation, kahoot, online quizzes, padlets and etc. will attract interest of students to study the civic education (Salleh \& Mohd Yunus, 2020). The integration of civic education should consider factors such as historical, political, religious and cultural setting in Malaysia. This can be done through a uniform curriculum for all schools such as same textbook, language, pedagogy, classroom climate, assessment and school culture. In order to achieve multicultural tolerance in Malaysia, strong basic foundation must be built which can be done through the implementation of civic curriculum in the Malaysian education system.

Civic curriculum can take place with emphasis on the elements of knowledge, skills, attitudes and practices of teaching, learning and assessment. Therefore, the civic curriculum framework must not be racially biased, embracing only dominant ethnic values, unfairness to other ethnics (Sahal et. al., 2018) that will result in social disorder, thus disrupting the aims of achieving peace and harmonious relationship among races (Crocco, 2017; Purta, 2002). The process and product of a curriculum can be translated through the framework of curriculum development In implementing an integrated civic curriculum, interaction and coordination between diverse organizations are required to enable that the tensions between religion, cultural norms, and ethics could be resolved. Educators, students, parents, and the general public should meet regularly to decide on controversial issues and find ways to ensure that everyone in society has the understanding, abilities, and values required for digital citizenship to prosper (Balakrishnan, 2021). 


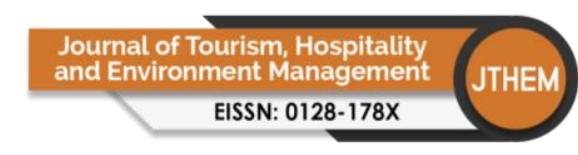

Volume 6 Issue 25 (October 2021) PP. 15-27

DOI 10/35631/JTHEM.625002

Teacher's Competency

Special Issue: Sustainable Development Goals (SDGS) 2030

Previous literature demonstrated the lack of effectiveness of civic education courses in changing the attitude and level of civic engagement of students (Purta, 2002; Purta et al,2005). Thus, it is important for the teachers to strike a balanced method and approach in promoting civic education because, through civic education in school, students will be able to understand the diversity and uniqueness of the various races, cultures and customs in the community which could promote multicultural tolerance among them (Salleh \& Yunus, 2020). Teaching not only involve pedagogical knowledge of the teachers, but it also demand the teacher's knowledge about domain of the curriculum (Nogueira \& Moreira, 2012). Professional competence is needed for the teachers to provide meaningful and beneficial learning activities for students (Adawiah, 2020), hence teachers need to master in using teaching materials widely and deeply so that they will not fail to approach civic curriculum in a new way especially in the age of technological and internet developments where fake news can easily spread which can result in racial sentiments. Based on the arising tension between racial groups as discussed earlier, therefore it is time to give more exposure to teachers on how to handle student's discipline effectively rather than just focusing on pedagogical skills training.

Students need to understand the multicultural values which are inherent in Malaysian society. Therefore, teachers play a big role to employ better pedagogical techniques to build a democratic classroom climate that would positively influence the civic attitudes of students (Mitchell, 2017). They are the key elements for effectiveness and success in school, therefore their role in the promotion of civic education cannot be ignored (Nogueira \& Moreira, 2012). Besides teachers, schools also have been seen as a good platform to instil unity and develop social cohesion among citizen. Studies have been conducted on the contribution of schools to students' civic engagement (Purta, 2002). Thus, it is important for schools to be a platform to enhance personality and communication between teachers and students of different racial and cultural backgrounds.

\section{Conclusion}

Malaysia is a unique nation of diverse races and culture, a tolerated generation and citizens are very much needed to establish as harmonious, peaceful nation. Therefore, education plays critical aspect of such development. Hence, tolerance among citizens of diverse race and ethnicity should be instilled from young age. This is a long overdue process which could only be achieved through education. Students should be educated, exposed and to be made aware of necessary value for multicultural tolerance from the onset of schooling. Early exposure to civic awareness and citizenship from childhood to adolescence would help build a nation that is patronized and loved. Thus, the school is the best platform for educating and fostering unity through civic education. As for the civic education curriculum needs to focus on patriotism and national identity in order to achieve harmony. This could be achieved if the curriculum, the teaching approach and teacher's competency encompassing all necessary element needed to produce outcome of national unity among races in Malaysia.

\section{Acknowledgment}

This article is part of the UMS and UPSI (TLS2113) collaborative publishing grant sponsorship funded by Global Academic Excellence (GAE). The authors would like to express their deepest heartfelt appreciation to Global Academic Excellence (GAE) for providing funding this publication. 


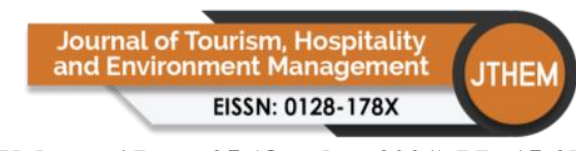

Volume 6 Issue 25 (October 2021) PP. 15-27

DOI 10/35631/JTHEM.625002

\section{References}

Special Issue: Sustainable Development Goals (SDGS) 2030

Adawiah, R. (2020). Pancasila and Civic Education Teacher Organization Role in Improving Professionality of Civic Education Teachers. Proceedings of the 2nd Annual Civic Education Conference (ACEC 2019). https://doi.org/10.2991/assehr.k.200320.079

Adnan, A.H., \& Smith, E. (2001). The social functions of education in a developing country: The case of Malaysian school and role of Malaysian teachers". Intercultural Education. Vol. 12. Issue 3. P.325-337.

Afdal, G. (2005). Tolerance and Curriculum: Conceptions of Tolerance in the Multicultural Unitary Norwegian Compulsory School. Munster, Germany. Waxmann.

Alias, N., Nordin, A.B., Siraj,S., Abdul Rahman, M.N., (2014). Kurikulum: Satu Disiplin yang Dinamik. Kuala Lumpur: Pearson Malaysia Sdn Bhd.

Balakrishnan, V. (2021). Civics education in Malaysia: a clash between ethics, religion and cultural norms", Asian Education and Development Studies, Vol. ahead-of-print No. ahead-of-print. https://doi.org/10.1108/AEDS-09-2020-0225

Hamdan, A. Rahim. (2009). Pengajian Kurikulum. Edisi ke-2. Skudai: Universiti Teknologi Malaysia.

Ahmad, A. R., Saleha, A., Jelas, Z. M., \& Seman, A.A. (2010). Kepelbagaian Pelajar dan Sekolah: Satu Kajian Kes di Negeri Pahang. Jurnal Pendidikan Malaysia, 35 (2). pp. 87-95.

Carretero, M., Haste, H., \& Bermudez, A. (2016). Civic education. In L. Corno \& E. M. Anderman (Eds.), Handbook of educational psychology (pp. 295-308). Routledge/Taylor \& Francis Group

Crocco, M. S. (2017). The Challenges of Multicultural Education in Two Globalizing Democratic Societies. Theory \& Research in Social Education, 45(3), 422-425.

Dalton, J. \& Crosby, P., (2010) How We Teach Character in College: A Retrospective on Some Recent Higher Education Initiatives That Promote Moral and Civic Learning, Journal of College and Character, 11:2, DOI: 10.2202/1940-1639.1264.

Embi, M. A. (2015). Kepelbagaian Pelajar dan Perbezaan Pembelajaran. Kuala Lumpur: Dewan Bahasa dan Pustaka.

Fakhri R Khader (2012), The Malaysian Experience in Developing National Identity, Multicultural Tolerance and Understanding through Teaching Curricula: Lessons Learned and Possible Applications in the Jordanian Context. International Journal of Humanities and Social Science. Vol. 2 No. 1

Fisher, S., \& Kartikasari, S. N. (2001). Mengelola konflik: ketrampilan \& strategi untuk bertindak. Jakarta: Zed Books; British Council.

Mahmood, H. (2014). Civics and citizenship education in Malaysia: The voice of micro policy enactors (Doctoral dissertation, Cardiff University).

Hairom, N. (2020, 9 Disember). Pendirian Dong Zong Berhubung Isu Tulisan Jawi Konsisten. Accessed from https://www.sinarharian.com.my/article/114071/BERITA/Nasional/Pendirian-DongZong-berhubung-isu-tulisan-jawi-konsisten

Hashim, A. T., Bakar, I. A., Osman, R., Mamat, N., \& Razali, A. R. (2015). Strengthening relationship among multi-ethnic students in Malaysia. Journal of Research, Policy \& Practice of Teachers and Teacher Education, 5(1), 17-29.

Ishak, Mohd. (2009). Cultural and Religious Tolerance: The Malaysian Experience". International Conference on Migration, Citizenship and Intercultural Relations, 19-20 November. Deacon University, Australia. 


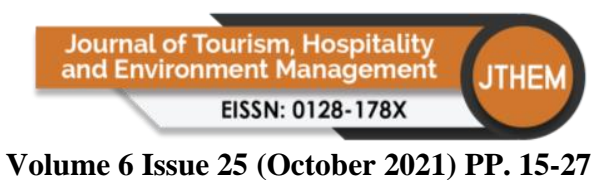

Volume 6 Issue 25 (October 2021) PP. 15-27

DOI 10/35631/JTHEM.625002

Special Issue: Sustainable Development Goals (SDGS) 2030

Jamaluddin, M. K. A. M. (2011). Sistem Pendidikan Di Malaysia: Dasar, Cabaran Dan Pelaksanaan Ke Arah Perpaduan Nasional. Jurnal Sosiohumanika 4(1): 2-16.

Kamus Dewan (2005). Edisi keempat. Kuala Lumpur: Dewan Bahasa dan Pustaka, 823.

Kementerian Pendidikan Malaysia (1989), Kurikulum Bersepadu Sekolah Menengah (The Integrated Secondary School Curriculum).

Kementerian Pendidikan Malaysia (1990), The New Primary School Curriculum.

Koriakina, A. A., Tretyakova, T. V., Ignatiev, V. P. \& Olesova, S. G. (2019) Formation of Tolerance in Multicultural Educational Environment. Education, 40 (9), 16.

Malik, M. (2019, 10 Mei). Kenapa Pendidikan Sivik diperkenal? Accessed from https://www.malaysiakini.com/columns/488181

Moorthy, R., Selvadurai, S., Gill, S. S., \& Gurunathan, A. (2021). Sustainable societal peace through the integration of bioethics principles and value-based education. Sustainability, 13(6), 3266. https://doi.org/10.3390/su13063266

McKimm, J. (2010). Curriculum design and development.Medical Education, 1-32, 2007. British Journal of Hospital Medicine (2005) 71 (6), 342-344, 2010.

Mitchell, D. R. (2017). Diversities in education: effective ways to reach all learners. Abingdon, Oxon: Routledge.

National Philosophy of Education, Accessed from https://kheru2006.webs.com/national_philosophy_of_education.htm

Nogueira, F., \& Moreira, A. (2012). A framework for civic education teachers' knowledge. Procedia - Social and Behavioral Sciences, 47, 1179-1183. https://doi.org/10.1016/j.sbspro.2012.06.797

Pala, A. (2017). The Need for Character Education. International Journal of Social Sciences and Humanity Studies. Vol 3, No 2, 2011 ISSN: 1309-8063.

Pengarang, L. (2020, 08 September) Isu sekolah vernakular terus diperdebatkan. Accessed from https://www.sinarharian.com.my/article/100151/SUARA-SINAR/LidahPengarang/Isu-sekolah-vernakular-terus-diperdebatkan.

Purta, J. T., Richardson, W. K., \& Barber, C. H. (2005). Teachers' Educational Experience and Confidence In Relation To Students' Civic Knowledge across Countries. International Journal of Citizenship and Teacher Education, 1(1), 32-57.

Purta, J. T (2002) The School's Role in Developing Civic Engagement: a study of adolescents in twenty-eight countries. Applied Developmental Science, 6, 4, 203-212.

Razali, S.A. (2020, 24 Ogos) Lima ditahan pasang Jalur Gemilang terbalik. Accessed from https://www.bharian.com.my/berita/kes/2020/08/724382/lima-ditahan-pasang-jalurgemilang-terbalik

Sahal, M., Musadad, A. A., \& Akhyar, M. (2018). Tolerance in Multicultural Education: A Theoretical Concept. International Journal of Multicultural and Multireligious Understanding, 5(4), 115

Salleh, S. (2018). Integrating Islamic Education in Multiracial and Multicultural Society in Malaysia. eProsiding: ICIRKED 2018, 27th-28th November 2018 International Conference on Islamic Revealed Knowledge Education.

Salleh, S. \& Mohd. Yunus, A. (2020). Nation Buliding: Promoting Patrotisme among Higher Education Students Through Civic Education. eProsiding: Moral, Civics And Character Education International Conference MCCEIC. March 11th-12th , 2020.

Salleh, S. Mohd. Yunus, A., Che Noh, M. A (2020). Character Education Framework for Multiracial Society in Malaysia. International Journal of Advanced Science and Technology Vol. 29, No. 8, (2020), pp.4035-4041 


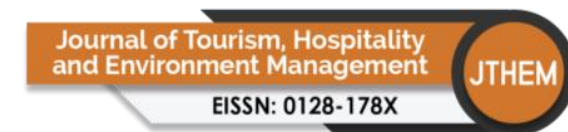

Volume 6 Issue 25 (October 2021) PP. 15-27

DOI 10/35631/JTHEM.625002

Special Issue: Sustainable Development Goals (SDGS) 2030

Sleeter, C. (2018). Multicultural Education Past, Present and Future: Struggles for Dialog and Power-Sharing. International Journal of Multicultural Education. Vol 20, issue 1, page 5- 20.

Sheehan, J. (1986). Curriculum Models: Product versus Process. Journal of Advanced Nursing 11:671-678.

Stenhouse, L. 1975. An Introduction to Curriculum Research and Development. London: Heinemann Educational Books Ltd.

Suhaini, N.A. (2020, 12 Ogos ) 4 ditahan pasang bendera terbalik. Accessed from https://www.bharian.com.my/berita/kes/2020/08/720368/4-ditahan-pasang-benderaterbalik

Tamuri, A. H., \& Hussin, N. H. (2011). Pendidikan Abad ke 21 Dalam Kepelbagaian Budaya: Cabaran dan Harapan. Kertas Kerja Ucaputama Seminar Pedagogi Antarabangsa ke-8 (PEDA8), Kuala Lumpur.

Yusof, N. M., \& Esmaeil, Z. J. (2017). Reconstructing Multiculturalism in Malaysia through Visual Culture. Mediterranean Journal of Social Sciences, 8(4-1), 99-105. doi: 10.2478/mjss-2018-0078

Walzer, M., (1997). On Toleration. Yale University Press. 